\title{
Incorporating carbon nanotube in a low-temperature fabrication process for dye-sensitized $\mathrm{TiO}_{2}$ solar cells is
}

\author{
Kun-Mu Lee ${ }^{\mathrm{a}}$, Chih-Wei Hu ${ }^{\mathrm{a}}$, Hsin-Wei Chen ${ }^{\mathrm{b}}$, Kuo-Chuan Ho ${ }^{\mathrm{a}, \mathrm{b}, *}$ \\ a Institute of Polymer Science and Engineering, National Taiwan University, Taipei 10617, Taiwan \\ ${ }^{\mathrm{b}}$ Department of Chemical Engineering, National Taiwan University, Taipei 10617, Taiwan
}

\section{A R T I C L E I N F O}

\section{Article history:}

Received 20 December 2007

Received in revised form

22 July 2008

Accepted 23 July 2008

Available online 29 August 2008

\section{Keywords:}

Carbon nanotube

Dye-sensitized solar cells

EIS

Low-temperature fabrication

$\mathrm{TiO}_{2}$ electrode

\begin{abstract}
A B S T R A C T
Dye-sensitized solar cells (DSSCs) incorporating $\mathrm{TiO}_{2}$ porous films, prepared at a low temperature $\left(150^{\circ} \mathrm{C}\right.$ ), along with multi-wall carbon nanotubes (MWCNTs) were studied using two different electrolytes, namely LiI and THI. Electrochemical impedance spectroscopy (EIS) was employed to quantify the charge transport resistance and electron lifetime $\left(\tau_{\mathrm{e}}\right)$ under different levels (wt\%) of MWCNTs and electrolytes. The charge transport resistance at the $\mathrm{TiO}_{2} /$ dye/electrolyte interface $\left(R_{\mathrm{ct} 2}\right)$ increased as a function of the MWCNT concentration, which ranged $0.1-0.5 \mathrm{wt} \%$, due to a decrease in the surface area and decreased dye adsorption. The characteristic peak shifted to a lower frequency at $0.1 \mathrm{wt} \%$ of MWCNT, indicating a longer electron lifetime. The DSSC with the $\mathrm{TiO}_{2}$ electrode containing $0.1 \mathrm{wt} \%$ of MWCNT resulted in a higher short-circuited current density $\left(J_{\mathrm{SC}}\right)$ of $9.08 \mathrm{~mA} / \mathrm{cm}^{2}$, an opencircuit voltage $\left(V_{\mathrm{OC}}\right)$ of $0.781 \mathrm{~V}$, and a cell conversion efficiency of $5.02 \%$. EIS was also conducted under dark conditions. The large value at a middle frequency represented electron transport at the TiO $/ \mathrm{dye}$ electrolyte interface $\left(R_{\mathrm{rec}}\right)$. The $R_{\text {rec }}$ for $0.1 \mathrm{wt} \% \mathrm{MWCNT} / \mathrm{TiO}_{2}$ was found to be $114 \Omega$, and for those with 0.3 and $0.5 \mathrm{wt} \%$ were 35 and $30 \Omega$, respectively. The significantly higher value of $R_{\text {rec }}$ suggested that the charge recombination between injected electrons and electron acceptors in the redox electrolyte, $\mathrm{I}_{3}^{-}$, was remarkably retarded. Finally, electrolytes with LiI and THI were used to compare the cell conversion performance under the same conditions. It was found that more electrons were injected in the $\mathrm{TiO}_{2}$ electrode and the electron recombination reaction was faster in the DSSC with THI than that with LiI. (c) 2008 Elsevier B.V. All rights reserved.
\end{abstract}

\section{Introduction}

Dye-sensitized solar cells (DSSCs) have attracted much attention as the next-generation solar cells with low production costs and good efficiency for energy conversion, reaching $11 \%$ and a module efficiency of $7 \%$ in some cases [1]. Their energy conversion working principle is based on injection of electrons from a photoexcited state of the sensitizer into the conduction band of the semiconductor. A charge mediator, i.e., a suitable redox couple, must be added to the electrolyte to reduce the oxidized dye. The mediator also needs to be renewed in the counter-electrode, meaning that the photoelectrochemical cell can be regenerated.

At present, research work has focused on developing inexpensive solar cells based on flexible plastic substrates such as

The paper was presented at the International Materials Research Congress (IMRC), Symposium 4-Photovoltaics, Solar Energy Materials and Thin Films, October 28-November 1, 2007, Cancun, Mexico.

* Corresponding author at: Department of Chemical Engineering, National Taiwan University, Taipei 10617, Taiwan. Tel.: +8862 2366 0739; fax: +886223623040.

E-mail address: kcho@ntu.edu.tw (K.C. Ho). nanocrystalline $\mathrm{TiO}_{2}$ electrodes and counter-electrodes [2]. However, the conventional method for preparing $\mathrm{TiO}_{2}$ electrodes for DSSCs using colloidal suspensions of $\mathrm{TiO}_{2}$ nanoparticles includes high-temperature sintering at $450-500^{\circ} \mathrm{C}$, in order to remove organic additives such as the precursor or polymer for the interconnection between $\mathrm{TiO}_{2}$ particles and the substrate. This is also necessary to establish a good interconnection among $\mathrm{TiO}_{2}$ particles; however, it cannot be applied to prepare films on plastic substrates because they crack at such high temperatures.

The development of low-temperature fabrication methods should overcome two main problems of incomplete necking of the particles and the presence of residual organics in the film [3]. These problems cause lower electron diffusion coefficients and electron lifetimes. Therefore, enhancing the electron transport rate and electron lifetime is compulsory for low-temperature fabrication processes. Recently, some efforts have been made to develop methods compatible with plastic substrates [4-9], and the conversion efficiency level reached 5.8\% under irradiation of $100 \mathrm{~mW} / \mathrm{cm}^{2}$ [9].

Carbon nanotubes (CNTs) are remarkable materials, which are being widely studied because of their extraordinary electronic 
and mechanical properties. Some reports have shown that incorporation of CNTs in a poly(3-octylthiophene) polymer film enhanced the electrical conductivity of the composite film [10,11]. A composite of poly( $p$-phenylene vinylene) with CNTs in a photovoltaic device showed good quantum efficiency, owing to the formation of a complex interpenetrating network with the polymer chains [12]. The CNTs also conferred electrical conductivity to metal oxide nanocomposites [13]. However, only a few reports have been found in the literature where CNTs are used along with $\mathrm{TiO}_{2}$ films in DSSCs [14-16], despite the expected potential to enhance the solar energy conversion efficiency due to favorable electrical conductivity. To the best of our knowledge, those reports which are associated with the addition of CNTs to $\mathrm{TiO}_{2}$ films focused on high-temperature fabrication of $\mathrm{TiO}_{2}$ electrodes, while no report was found which deals with the application of $\mathrm{TiO}_{2}$ electrodes containing CNTs fabricated at low temperature in DSSCs. Herein, we investigated these aspects in order to improve the electrical conductivity of $\mathrm{TiO}_{2}$ films.

In addition, electrochemical impedance spectroscopy (EIS) is a useful tool for analyzing the charge transport process. EIS is a steady-state technique which measures the current response to the application of an AC voltage as a function of the frequency [17]. EIS has been widely employed to study the kinetics of electrochemical and photoelectrochemical processes, including elucidation of the salient electronic and ionic processes occurring in DSSCs [18-20]. In this study, we utilized EIS to analyze the charge transport resistances in DSSCs. By fitting and calculating the exact resistance, capacitance, and time constants of DSSCs in Nyquist plots, the effects of MWCNTs on the $\mathrm{TiO}_{2}$ electrodes fabricated with a low-temperature process in DSSCs were investigated.

\section{Experimental}

\subsection{Materials}

Anhydrous $\mathrm{I}_{2}$, ethanol (99.5\%), tertiary butanol, and 4-tertiary butyl pyridine (TBP) were obtained from Merck, and titanium (IV) tetraisopropoxide (TTIP) (>98\%) was purchased from Acros; all were used as received. Cis-di(thiocyanato)bis(2,2'-bipyridyl-4,4'dicarboxylate) ruthenium (II) (N3 dye) is a commercial product of Solaronix (Aubonne, Switzerland). MWCNTs were purchased from Nanotech Port (Taiwan). These MWCNTs were produced via a chemical vapor deposition (CVD, sometimes called catalytic pyrolysis) method [21]. The MWCNTs were oxidized in a concentrated $3: 1 \mathrm{v} / \mathrm{v}$ acid mixture of $\mathrm{H}_{2} \mathrm{SO}_{4} / \mathrm{HNO}_{3}$ under ultrasonication for $24 \mathrm{~h}$ at $50-60{ }^{\circ} \mathrm{C}$ to produce MWCNTs with terminal $-\mathrm{COOH}$ groups [22]. We expected that after the acid treatment the MWCNTs with terminal - $\mathrm{COOH}$ groups would have good contact around the $\mathrm{TiO}_{2}$ nanoparticles.

\subsection{Preparation of $\mathrm{TiO}_{2}$ electrodes}

The $\mathrm{TiO}_{2}$ precursor and electrodes were prepared according to the procedures described in the literature [8]. TTIP and P25 $\mathrm{TiO}_{2}$ were mixed at a molar ratio of $0.08 / 1$ in an ethanol solution, and various amounts of acid-treated MWCNTs were added to the $\mathrm{TiO}_{2}$ paste and dispersed using an ultrasonic horn for $30 \mathrm{~min}$. After stirring for $2 \mathrm{~h}$, the paste was coated onto fluorine-doped $\mathrm{SnO}_{2}$ coated conductive glass ( $15 \Omega / \mathrm{sq}$. FTO glass) using a glass rod, followed by evaporation of the ethanol in air at room temperature after a few minutes. Then the films that had formed were sintered at $150^{\circ} \mathrm{C}$ for $4 \mathrm{~h}$.

\subsection{Cell assembly of DSSCS}

An active area of $0.25 \mathrm{~cm}^{2}$ was selected from the sintered electrode, and the electrodes were immersed in a $3 \times 10^{-4} \mathrm{M}$ solution of N3 dye containing acetonitrile and tertiary butanol (in a volume ratio of $1: 1)$ overnight. Pt ( $100 \mathrm{~nm}$ thick) sputtered onto the FTO was used here as the counter-electrode.

Cells were fabricated by applying an ionomer resin (Surlyn 1702, Dupont, USA), at a thickness of $50 \mu \mathrm{m}$, between the two electrodes, and then two holes were made on the resin. The whole setup was heated to $100^{\circ} \mathrm{C}$ on a hotplate until all of the resin had been melted, and the electrolyte was injected into the space between the electrodes through these two holes. Finally, these two holes were completely sealed using Torr Seal ${ }^{\circledR}$ cement (Varian, MA, USA). The electrolyte was composed of $0.5 \mathrm{M}$ LiI/0.05 $\mathrm{M} \mathrm{I}_{2} / 0.5 \mathrm{M}$ TBP in $\mathrm{CH}_{3} \mathrm{CN}$.

\subsection{Instruments and measurements}

Photoelectrochemical characterizations of the DSSCs were carried out using AM 1.5 simulated light irradiation. The light source was a $450 \mathrm{~W}$ Xe lamp ( $\$ 6266$, Oriel, USA) equipped with a water-based infrared (IR) filter and an AM 1.5 filter ( $\$ 81075$, Oriel). UV-visible absorption data were measured by a UV-visible spectrophotometer (V-570, Jasco, Japan). Photoelectrochemical characteristics and EIS measurements of the DSSCs were recorded with a potentiostat/galvanostat (PGSTAT 30, Autolab, Eco-Chemie, The Netherlands). The frequency range explored was from $10 \mathrm{mHz}$ to $65 \mathrm{kHz}$. The applied bias voltage and AC amplitude were set at the open-circuit voltage of the DSSCs and $10 \mathrm{mV}$ between the $\mathrm{FTO} / \mathrm{Pt}$ counter electrode and the $\mathrm{FTO} / \mathrm{TiO}_{2}$ /dye working electrode, respectively, starting from a short-circuit condition [23]. The impedance spectra were analyzed by an equivalent circuit model which interpreted the characteristics of the DSSCs [24]. The photovoltage transients of the assembled devices were recorded with a digital oscilloscope (model LT322, LeCroy, USA). Pulsed laser excitation was applied by a frequency-doubled Q-switched Nd:YAG laser (model Quanta-Ray GCR-3-10, Spectra-Physics laser) with a $2 \mathrm{~Hz}$ repetition rate at $532 \mathrm{~nm}$, and a $7 \mathrm{~ns}$ pulse width at half-height. The beam size was slightly larger than $0.25 \mathrm{~cm}^{2}$ to cover the area of the device with an incident energy of $1 \mathrm{~mJ} / \mathrm{cm}^{2}$. The average electron lifetime can approximately be estimated by fitting a decay of the open-circuit voltage transient with $\exp \left(-t / \tau_{\mathrm{e}}\right)$, where $t$ is the time and $\tau_{\mathrm{e}}$ is an average time constant before recombination.

\section{Results and discussion}

Acid-treated MWCNT and P25 $\mathrm{TiO}_{2}$ nanoparticles were used to fabricate the $\mathrm{TiO}_{2}$ photoelectrodes in this study. Due to the favorable electrical conductivity of the CNTs on metal oxide nanocomposites [13], we expected that the presence of the CNTs should enhance the electron transport rate and extend the electron lifetime in the $\mathrm{TiO}_{2}$ electrode, so as to improve the solar energy conversion efficiency. In addition, from the literature [22], it was noted that the oxidation of CNTs in a concentrated acid treatment could produce CNTs with terminal - $\mathrm{COOH}$ groups, which have better contact around $\mathrm{TiO}_{2}$ nanoparticles to improve the collection of electrons. The TEM images of MWCNTs and P25 $\mathrm{TiO}_{2}$ particles, and the SEM images of the $\mathrm{TiO}_{2}$ electrode containing $0.1 \mathrm{wt} \% \mathrm{MWCNT}$ in the $\mathrm{TiO}_{2}$ are shown in Fig. 1. From the SEM images, we found that the MWCNTs were well-dispersed among the $\mathrm{TiO}_{2}$ nanoparticles, and there was good contact between the MWCNTs and $\mathrm{TiO}_{2}$ nanoparticles. To optimize the ratio of 

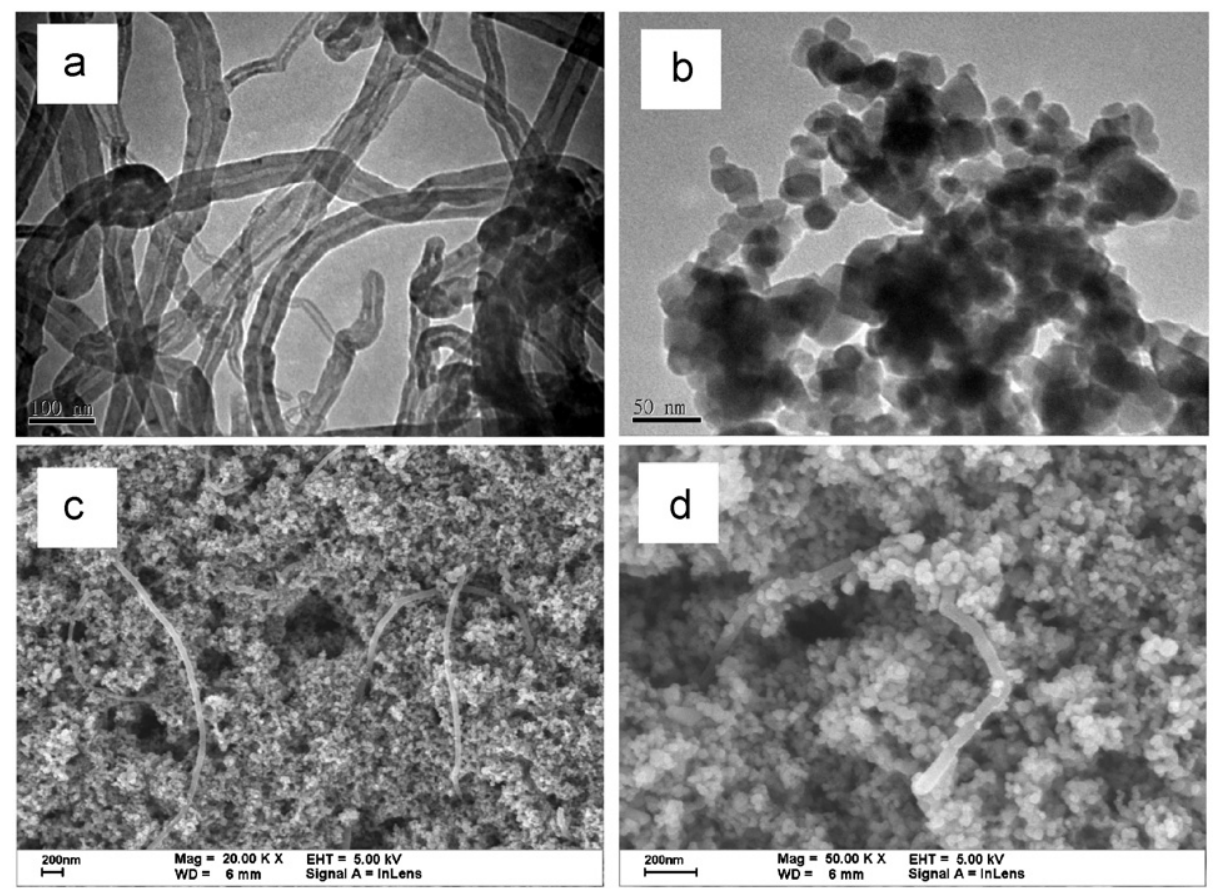

Fig. 1. TEM images of (a) MWCNT and (b) P25 $\mathrm{TiO}_{2}$. (c) and (d) are the SEM images of the side view of $0.1 \mathrm{wt} \% \mathrm{MWCNT} / \mathrm{TiO} \mathrm{M}_{2}$ film.

MWCNTs with respect to $\mathrm{TiO}_{2}$ powder for film preparation, films composed of pastes with various weight percentages of MWCNTs were investigated. The EIS analysis of the DSSCs based on the $\mathrm{TiO}_{2}$ films with different ratios of MWCNTs/TiO $/ 2$ from 0 to $0.5 \mathrm{wt} \%$ are shown in Fig. 2. Generally speaking, the impedance spectra of the DSSCs exhibited three semicircles, which were assigned to the electrochemical reaction at the Pt counter electrode $\left(R_{\mathrm{ct} 1}\right)$ in the high-frequency region, to charge transfer at the $\mathrm{TiO}_{2} /$ dye/ electrode interface $\left(R_{\mathrm{ct} 2}\right)$ in the middle-frequency region, and to the Warburg diffusion process of $\mathrm{I}^{-} / \mathrm{I}_{3}^{-}$in the electrolyte $\left(R_{\mathrm{diff}}\right)$ in the low-frequency region. The overall series resistance of the cell $\left(R_{\mathrm{S}}\right)$ is the resistance measured when electrons are transported through the device in the high-frequency range exceeding $10^{6} \mathrm{~Hz}$. The Nyquist plot (Fig. 2a) showed that the $R_{\mathrm{S}}$ decreased from 40 to $\sim 26 \Omega$, as $\mathrm{TiO}_{2}$ particles were incorporated in the MWCNTs, which increased the conductivity of the $\mathrm{TO}_{2}$ film, resulting in a decrease in the $R_{\mathrm{S}}$ of the solar cells. The reduction in the $R_{\mathrm{S}}$ can improve the fill factor (FF) of the DSSCs to achieve a higher cell performance. Meanwhile, with the addition of $0.1 \mathrm{wt} \%$ of MWCNT to the $\mathrm{TiO}_{2}$ films, the value of the charge transport resistance at the $\mathrm{TiO}_{2} /$ dye/ electrolyte interface $\left(R_{\mathrm{ct} 2}\right)$ was almost the same as that using only the pure $\mathrm{TiO}_{2}$ electrode. However, with further increases in the amount of MWCNTs (from 0.3 to $0.5 \mathrm{wt} \%$ ), the $R_{\mathrm{ct} 2}$ increased (Fig. 2a). This phenomenon may have been due to a decrease in dye adsorption on the $\mathrm{TiO}_{2}$ electrode when the $\mathrm{TiO}_{2}$ film contained more MWCNTs, resulting in fewer electrons injected from the dye to the $\mathrm{TiO}_{2}$ electrode. Correspondingly, the characteristic frequency peaks $\left(1-10^{3} \mathrm{~Hz}\right)$ in the Bode phase plots (Fig. 2b) showed that the characteristic frequency peak shifted to a lower frequency when the MWCNT was at $0.1 \mathrm{wt} \%$ and then shifted back again to a higher frequency when the MWCNTs exceeded $0.3 \mathrm{wt} \%$. The characteristic frequency peak can be related to the inverse of the recombination lifetime $\left(\tau_{\mathrm{r}}\right)$, or electron lifetime $\left(\tau_{\mathrm{e}}\right)$ in $\mathrm{TiO}_{2}$ films [25-27]. This implies that the collection and transport of electrons in the $\mathrm{TiO}_{2}$ film were faster with $0.1 \mathrm{wt} \%$ of MWCNT than in its absence, thereby reducing the electron recombination and extending the electron lifetime in the $\mathrm{TiO}_{2}$ film. Nevertheless, when the content of MWCNTs exceeded
$0.3 \mathrm{wt} \%$, the surface area of the $\mathrm{TiO}_{2}$ with adsorbent dyes significantly decreased and the number of cracks on the surface of the porous $\mathrm{TiO}_{2}$ electrode increased, resulting in a lower current density. In addition, the surface of MWCNTs only had a few $-\mathrm{COOH}$ groups for dye adsorption even after the acid treatment. If the $\mathrm{TiO}_{2}$ film contained too many MWCNTs, the bare surfaces of the MWCNTs which are not covered by dyes would increase the electron recombination process on the working electrode surface, resulting in a lower $V_{\mathrm{OC}}$. The $J-V$ characteristics and EIS data of the DSSCs of $\mathrm{TiO}_{2}$ containing various amounts of MWCNTs measured under $100 \mathrm{~mW} / \mathrm{cm}^{2}$ are listed in Table 1 . Based on the bare $\mathrm{TiO}_{2}$ film, the cell conversion efficiency was about $4.15 \%$. In the cell with the $\mathrm{TiO}_{2}$ electrode containing $0.1 \mathrm{wt} \%$ of MWCNT, the $J_{\mathrm{SC}}$ was $9.08 \mathrm{~mA} / \mathrm{cm}^{2}, V_{\mathrm{OC}}$ was $0.781 \mathrm{~V}, \eta$ was $5.02 \%$ and $\mathrm{FF}$ was 0.708 . The value of $V_{\mathrm{OC}}$ increased from 0.761 to $0.781 \mathrm{~V}$ with a subsequent increase in MWCNTs of $0.0-0.1 \mathrm{wt} \%$. It has been observed that surface treatment usually increases the value of $V_{\mathrm{OC}}$ regardless of the nature and characteristics of the materials coated onto the electrode $[28,29]$. Furthermore, for the $\mathrm{TiO}_{2}$ electrode containing $0.1 \mathrm{wt} \%$ of MWCNT, the value of $J_{\mathrm{SC}}$ increased by about $14 \%$ from 7.96 to $9.08 \mathrm{~mA} / \mathrm{cm}^{2}$ compared to the as-prepared $\mathrm{TiO}_{2}$ electrode, due to enhancement of the collection and transport of electrons. The existence of MWCNTs in the $\mathrm{TiO}_{2}$ film increased the FF from 0.68 to $\sim 0.71$, which showed a better performance due to the increase in the conductivity of the $\mathrm{TiO}_{2}$ electrode. These results were also supported by the EIS analysis, as described above.

For comparison, the effect of MWCNT in the $\mathrm{TiO}_{2}$ electrode on the average electron lifetime $\left(\tau_{\mathrm{e}}\right)$ was also studied by a laserinduced photovoltage transient technique, and the results are shown in Fig. 3. The average electron lifetime can approximately be estimated by fitting a decay of the open-circuit voltage transient with $\exp \left(-t / \tau_{\mathrm{e}}\right)$, where $t$ is the time and $\tau_{\mathrm{e}}$ is an average time constant before recombination. It was found that values of $\tau_{\mathrm{e}}$ of $\mathrm{TiO}_{2}$ films were 2.75 and $2.00 \mathrm{~ms}$ for $\mathrm{TiO}_{2}$ electrode with and without $0.1 \mathrm{wt} \%$ of MWCNT, respectively. The study of $\tau_{\mathrm{e}}$ further proved the rationale that the $\mathrm{TiO}_{2}$ electrode containing $0.1 \mathrm{wt} \%$ of MWCNT possesses a reduced electron recombination and longer electron lifetime. 
a

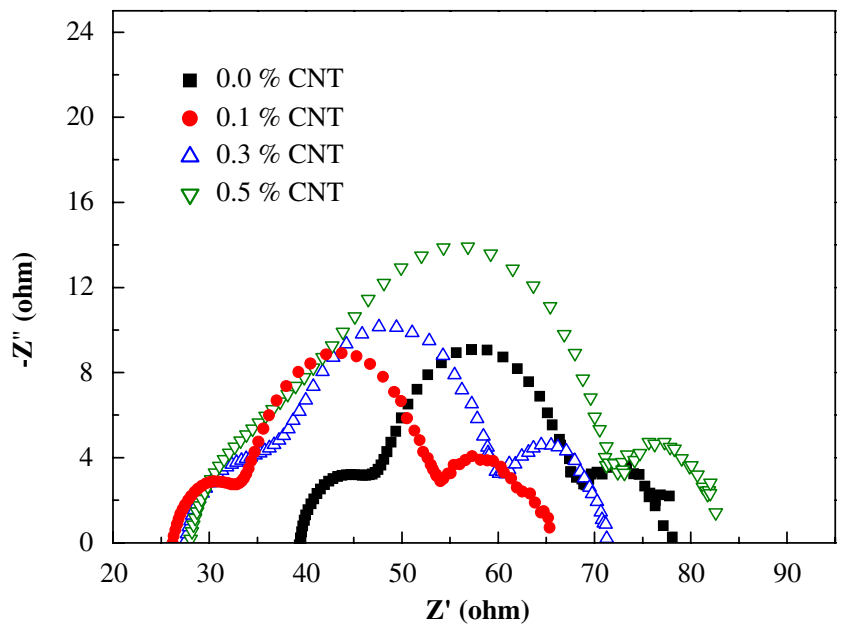

b

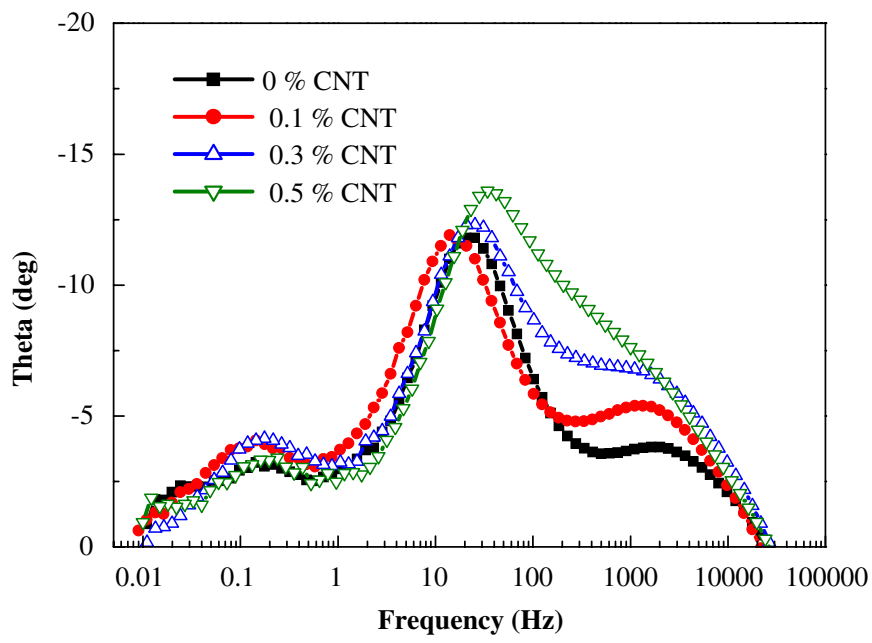

Fig. 2. Electrochemical impedance spectra of the DSSCs based on $\mathrm{TiO}_{2}$ electrode with different weight percents of MWCNTs measured at $-0.8 \mathrm{~V}, 100 \mathrm{~mW} / \mathrm{cm}^{2}$. (a) Nyquist plot and (b) Bode phase plot.

Table 1

The photovoltaic performances and impedance data of the DSSCs with lowtemperature fabricated $\mathrm{TiO}_{2}$ electrode containing various amounts of MWCNTs measured under $100 \mathrm{~mW} / \mathrm{cm}^{2}$

\begin{tabular}{llllllll}
\hline Sample (\% CNT) & $R_{\mathrm{S}}(\Omega)$ & $R_{\mathrm{ct} 2}(\Omega)$ & $\mathrm{CF}(\mathrm{Hz})^{\mathrm{a}}$ & $J_{\mathrm{SC}}\left(\mathrm{mA} / \mathrm{cm}^{2}\right)$ & $V_{\mathrm{OC}}(\mathrm{V})$ & $\eta(\%)$ & $\mathrm{FF}$ \\
\hline 0.0 & 40.0 & 21.4 & 20.5 & 7.96 & 0.761 & 4.15 & 0.685 \\
0.1 & 26.0 & 22.0 & 10.2 & 9.08 & 0.781 & 5.02 & 0.708 \\
0.3 & 27.5 & 28.7 & 25.3 & 6.52 & 0.740 & 3.43 & 0.710 \\
0.5 & 27.6 & 37.3 & 39.6 & 5.64 & 0.716 & 2.85 & 0.707
\end{tabular}

a $\mathrm{CF}$ : the peak frequency of the semicircle in the Nyquist plot.

The EIS of the DSSCs was also measured in the dark to elucidate the correlation of electron transport with different molar ratios. In these cells, electrons were transported through the mesoscopic $\mathrm{TiO}_{2}$ network and reacted with $\mathrm{I}_{3}^{-}$. At the same time, $\mathrm{I}^{-}$was oxidized to $\mathrm{I}_{3}^{-}$at the counter electrode. To further study the enhancement of $V_{\mathrm{OC}}$, EIS was measured at an applied bias voltage of $-0.8 \mathrm{~V}$ in the dark. Three semicircles were observed in the Nyquist plot. The large one in the middle frequency represents electron transport at the $\mathrm{TiO}_{2} /$ dye/electrolyte interface $\left(R_{\text {rec }}\right)$. The larger the $R_{\mathrm{rec}}$ is, the smaller the charge recombination rate will be. In Fig. 4 , values of $R_{\text {rec }}$ for $0.0,0.1,0.3$, and 0.5 wt\% of MWCNT

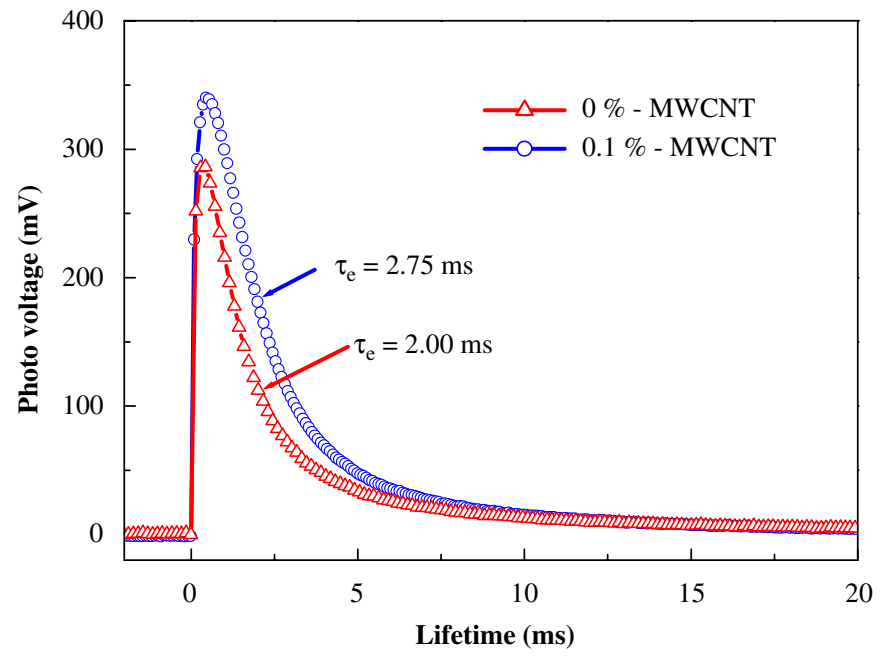

Fig. 3. Transient photovoltage measurements of the DSSCs with various $\mathrm{TiO}_{2}$ electrodes prepared with or without $0.1 \mathrm{wt} \%$ MWCNT.

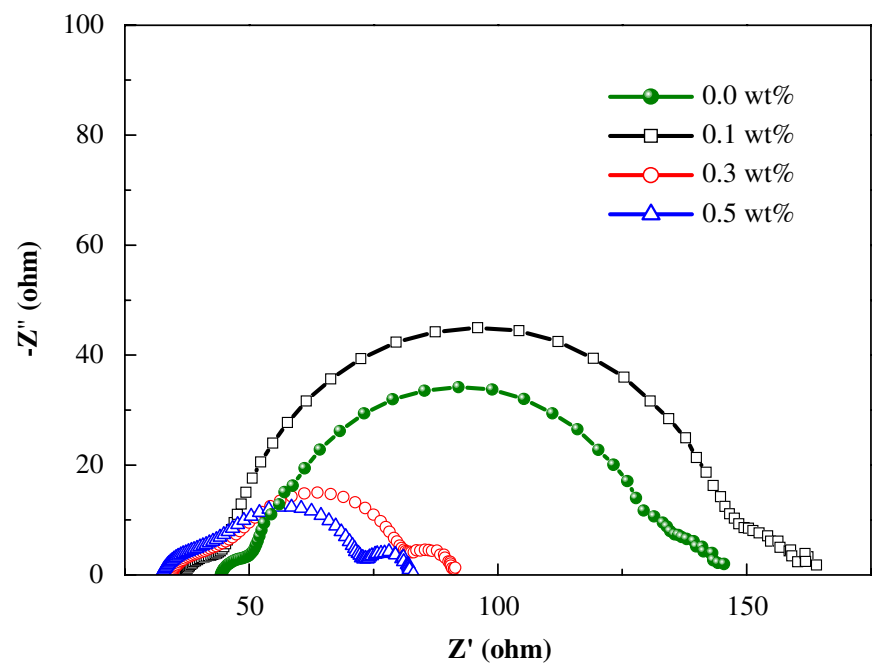

Fig. 4. The EIS measurement of the DSSCs with various $\mathrm{TiO}_{2}$ electrodes having various ratios of MWCNTs in the dark and applied $-0.8 \mathrm{~V}$.

in the $\mathrm{TiO}_{2}$ film were determined to be $89,114,35$, and $30 \Omega$, respectively. The significantly high $R_{\text {rec }}$ values suggest that charge recombination between injected electrons and electron accepters in the redox electrolyte, $\mathrm{I}_{3}^{-}$, was remarkably retarded.

Herein, the net current was largely dependent on the applied bias. The fitted data of the electron transport resistances and capacitances obtained from the Nyquist plots measured under different biases were obtained (data not shown), and the time constant can be calculated by Eq. (1)

$\tau_{\mathrm{n}}=R_{\mathrm{ct} 2} \times C_{\mu 2}$

where $R_{\mathrm{ct} 2}$ and $C_{\mu 2}$ are the charge transport resistance and the chemical capacitance at $\mathrm{TiO}_{2} /$ dye/electrolyte interface, respectively.

It was found that at the ratio of $0.1 \mathrm{wt} \%$ had higher resistances than the pure one, indicating that DSSCs based on the $\mathrm{TiO}_{2}$ electrode with 0.1 wt\% MWCNT had less recombination and a higher opencircuit voltage $\left(V_{\mathrm{OC}}\right)$. The chemical capacitances for DSSCs with and without MWCNT increased with an increase in the bias. The time constants of electrons in the $\mathrm{TiO}_{2}$ electrode increased with the forward bias, and it was also found to be higher at a ratio of $0.1 \mathrm{wt} \%$ as shown in Fig. 5, which revealed that devices containing the $\mathrm{TiO}_{2}$ 


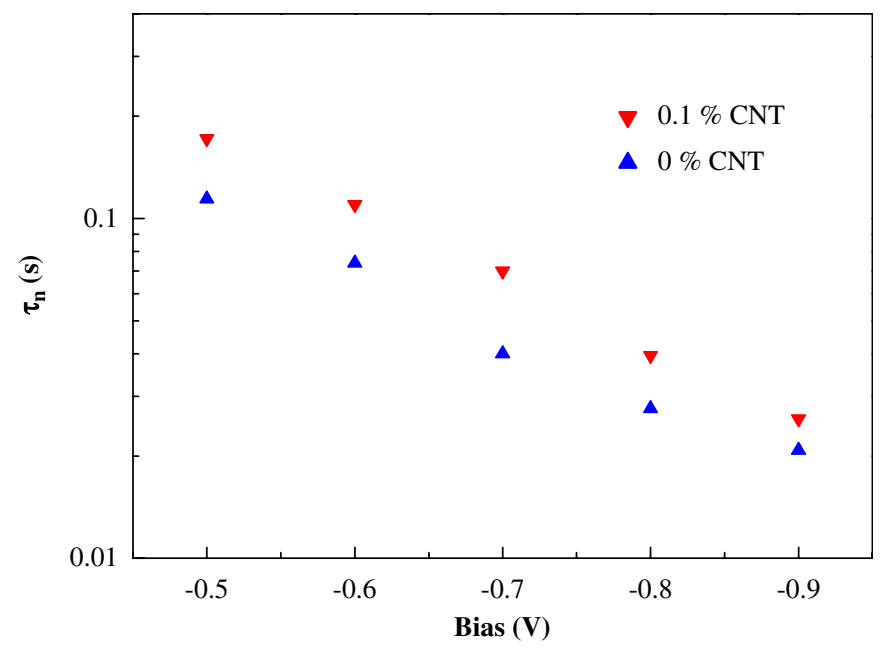

Fig. 5. The time constant of electron in $\mathrm{TiO}_{2}$ electrode of the DSSCs based on different wt\% of MWCNTs. The impedance measurement and the calculation are recorded in the dark and various applied biases.

a

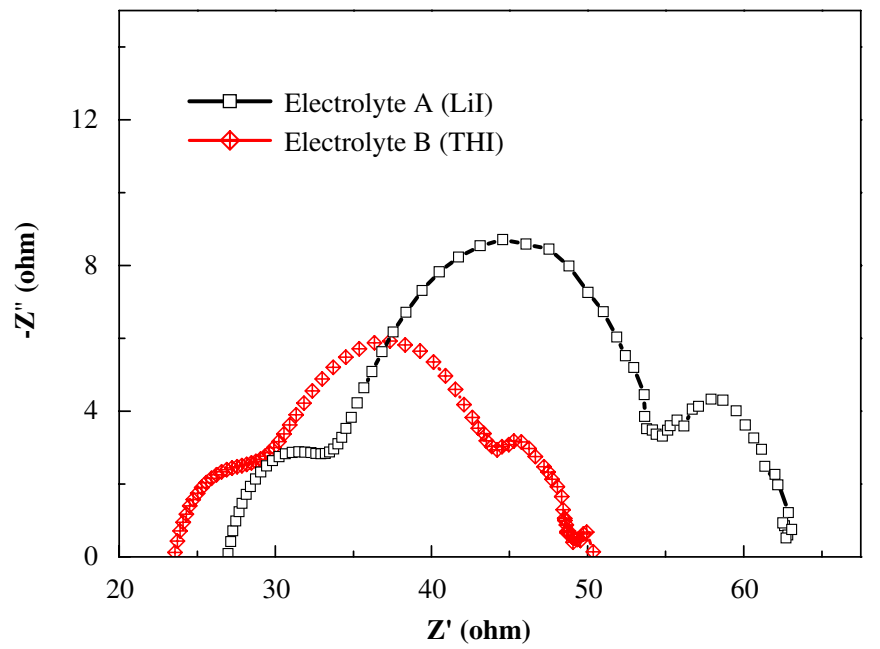

b

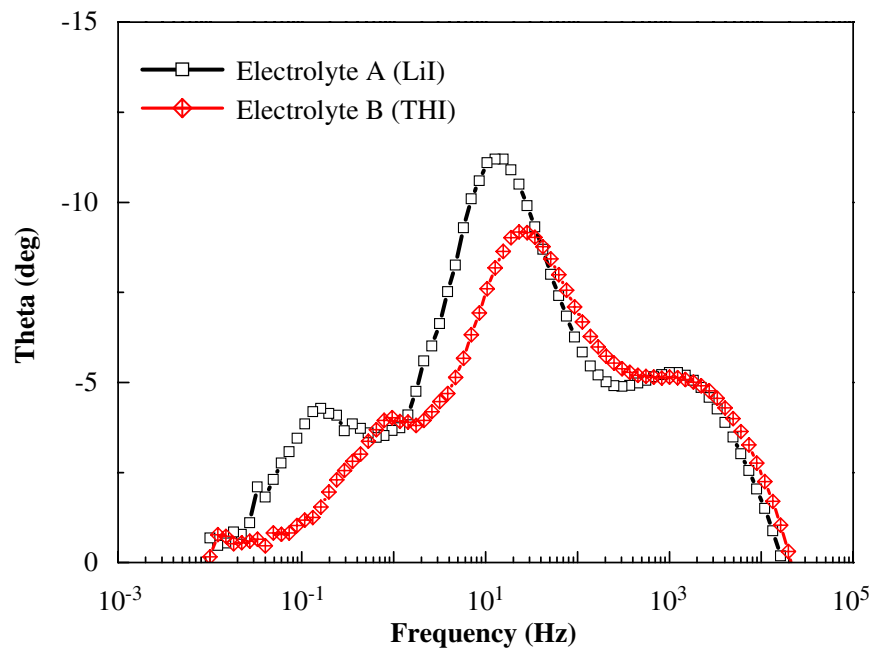

Fig. 6. EIS of the DSSCs based on $0.1 \mathrm{wt} \% \mathrm{MWCNT} / \mathrm{TiO}_{2}$ film with different electrolytes measured at $-0.8 \mathrm{~V}, 100 \mathrm{~mW} / \mathrm{cm}^{2}$. (a) Nyquist plot and (b) Bold phase plot.

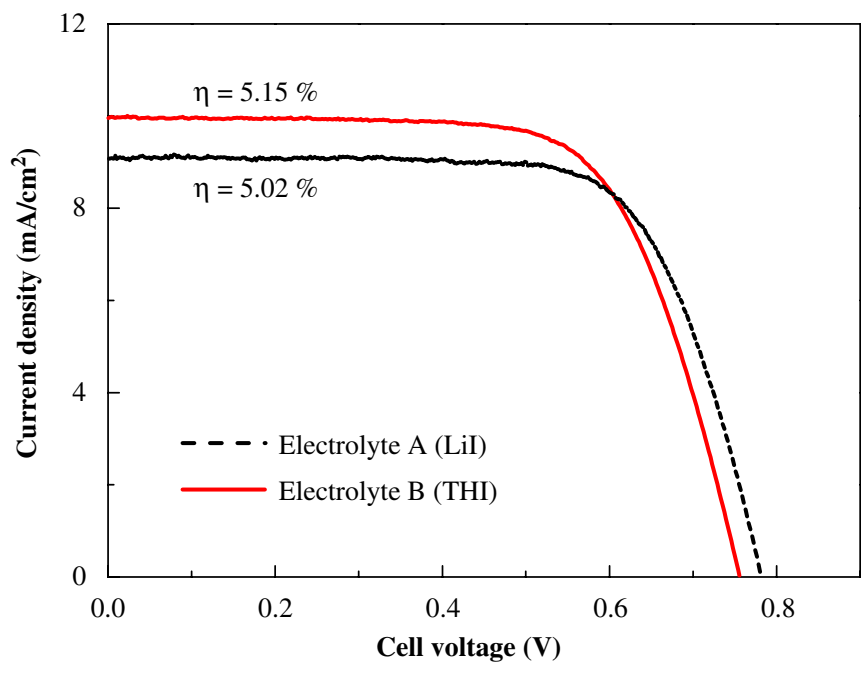

Fig. 7. The $J-V$ characteristic curves of DSSCs based on $0.1 \mathrm{wt} \% \mathrm{MWCNT} / \mathrm{TiO}_{2}$ film with different electrolytes.

electrode with $0.1 \mathrm{wt} \%$ MWCNT had a larger time constant due to the slower recapture of conduction-band electrons by $\mathrm{I}_{3}^{-}$. This result is consistent with the previous argument.

Finally, in order to understand the effect of different iodides, electrolytes with and without $\mathrm{Li}^{+}$were also studied based on the $\mathrm{TiO}_{2}$ electrode containing $0.1 \mathrm{wt} \%$ of MWCNT. Herein, LiI was replaced by THI, and the effect of THI on the DSSC performance had previously been studied in our laboratory [30]. The electrolyte containing LiI was named "electrolyte A" and the one with THI, "electrolyte B". In the Nyquist plot, the DSSC containing electrolyte B had a smaller $R_{\mathrm{ct} 2}$ than electrolyte A, but in the Bode plot, the characteristic frequency peak shifted to a high frequency when electrolyte B was used (Fig. 6). This observation suggests that more electrons were injected in the $\mathrm{TiO}_{2}$ electrode, but the electron recombination proceeded more easily in electrolyte $\mathrm{B}$ than electrolyte A. The $J-V$ characteristics of the DSSCs based on those electrolytes are shown in Fig. 7. It was found that the $J_{\mathrm{SC}}$ was $9.96 \mathrm{~mA} / \mathrm{cm}^{2}, V_{\mathrm{OC}}$ was $0.756 \mathrm{~V}, \eta$ was $5.15 \%$, and $\mathrm{FF}$ was 0.683 , using electrolyte $\mathrm{B}$. Although the value of $V_{\mathrm{OC}}$ decreased a little to $0.756 \mathrm{~V}$, the $J_{\mathrm{SC}}$ increased from 9.08 to $9.96 \mathrm{~mA} / \mathrm{cm}^{2}$, and the DSSC showed a better cell performance of $5.15 \%$.

\section{Conclusions}

DSSCs incorporated with $\mathrm{TiO}_{2}$ porous films prepared at a low temperature $\left(150^{\circ} \mathrm{C}\right)$ along with MWCNT containing two different electrolytes (LiI and THI) were investigated. The charge transport resistance at the $\mathrm{TiO}_{2} /$ dye/electrolyte interface $\left(R_{\mathrm{ct} 2}\right)$ increased as a function of the MWCNT from 0.1 to $0.5 \mathrm{wt} \%$, due to a decrease in the surface area and less dye adsorption. With $0.1 \mathrm{wt} \% \mathrm{MWCNT} / \mathrm{TiO}_{2}$, the DSSC had the highest cell performance and the longest electron lifetime in the $\mathrm{TiO}_{2}$ electrode. Finally, using THI instead of LiI in the electrolyte with a $\mathrm{TiO}_{2}$ electrode containing $0.1 \mathrm{wt} \%$ MWCNT, it was found that the $J_{\mathrm{SC}}$ increased, while the $V_{\mathrm{OC}}$ decreased and $\eta$ reached $5.15 \%$. This result suggests that more electrons were injected in the $\mathrm{TiO}_{2}$ electrode and the electron recombination reaction was faster in the DSSC with THI than that with LiI.

\section{Acknowledgments}

This work was partially supported by the National Research Council of Taiwan, the Republic of China, under Grant NSC 96- 
2120-M-002-016. Some instruments used in this study were financially supported by the Academia Sinica, Taipei, Taiwan, the Republic of China, under Grant AS-97-TP-A08. We also want to thank Professor King-Chuen Lin and his research group members, of the Department of Chemistry, National Taiwan University, for the help in making the pulsed laser apparatus available to us.

\section{References}

[1] M. Grätzel, Photoelectrochemical cells, Nature 414 (2001) 338-344.

[2] S.A. Haque, E. Palomares, H.M. Upadhyaya, L. Otley, R.J. Potter, A.B. Holmes, J.R. Durrant, Flexible dye-sensitized nanocrystalline semiconductor solar cells, Chem. Commun. (2003) 3008-3009.

[3] C. Longo, A.F. Nogueira, M.A. De Paoli, H. Cachet, Solid-state and flexible dyesensitized $\mathrm{TiO}_{2}$ solar cells: a study by electrochemical impedance spectroscopy, J. Phys. Chem. B 106 (2002) 5925-5930.

[4] T. Miyasaka, Y. Kijitori, T.N. Murakami, M. Kimura, S. Uegusa, Efficient nonsintering type dye-sensitized photocells based on electrophoretically deposited $\mathrm{TiO}_{2}$ layers, Chem. Lett. (2002) 1250-1251.

[5] D.S. Zhang, T. Yoshida, K. Furuta, H. Minoura, Hydrothermal preparation of porous nano-crystalline $\mathrm{TiO}_{2}$ electrodes for flexible solar cells, J. Photochem. Photobiol. A: Chem. 164 (2004) 159-166.

[6] N.G. Park, K.M. Kim, M.G. Kang, K.S. Ryu, S.H. Chang, Y.J. Shin, Chemical sintering of nanoparticles: a methodology for low-temperature fabrication of dye-sensitized $\mathrm{TiO}_{2}$ films, Adv. Mater. 17 (2005) 2349-2353.

[7] G. Boschloo, J. Lindstrom, E. Magnusson, A. Holmberg, A. Hagfeldt, Optimization of dye-sensitized solar cells prepared by compression method, J. Photochem. Photobiol. A: Chem. 148 (2002) 11-15.

[8] D.S. Zhang, T. Yoshida, T. Oekermann, K. Furuta, H. Minoura, Roomtemperature synthesis of porous nanoparticulate $\mathrm{TiO}_{2}$ films for flexible dyesensitized solar cells, Adv. Funct. Mater. 16 (2006) 1228-1234.

[9] T. Miyasaka, M. Ikegami, Y. Kijitori, Photovoltaic performance of plastic dyesensitized electrodes prepared by low-temperature binder-free coating of mesoscopic titania, J. Electrochem. Soc. 154 (2007) A455-A461.

[10] E. Kymakis, I. Alexandou, G.A.J. Amaratunga, Single-walled carbon nanotube-polymer composites: electrical, optical and structural investigation, Synth. Met. 127 (2002) 59-62.

[11] I. Musa, M. Baxendale, G.A.J. Amaratunga, W. Eccleston, Properties of regioregular poly(3-octylthiophene)/multi-wall carbon nanotube composites, Synth. Met. 102 (1999) 1250.

[12] H. Ago, K. Petritsch, M.S.P. Shaffer, A.H. Windle, R.H. Friend, Composites of carbon nanotubes and conjugated polymers for photovoltaic devices, Adv. Mater. 11 (1999) 1281-1285.

[13] E. Flahaut, A. Peigney, C. Laurent, C. Marliere, F. Chastel, A. Rousset, Carbon nanotube-metal-oxide nanocomposites: microstructure, electrical conductivity and mechanical properties, Acta Mater. 48 (2000) 3803-3812.
[14] S.R. Jang, R. Vittal, K.J. Kim, Incorporation of functionalized single-wall carbon nanotubes in dye-sensitized $\mathrm{TiO}_{2}$ solar cells, Langmuir 20 (2004) 9807-9810.

[15] T.Y. Lee, P.S. Alegaonkar, J.B. Yoo, Fabrication of dye-sensitized solar cell using $\mathrm{TiO}_{2}$ coated carbon nanotubes, Thin Solid Films 515 (2007) 5131-5135.

[16] S.L. Kim, S.R. Jang, R. Vittal, J. Lee, K.J. Kim, Rutile $\mathrm{TiO}_{2}$-modified multi-wall carbon nanotubes in $\mathrm{TiO}_{2}$ film electrodes for dye-sensitized solar cells, J. Appl. Electrochem. 36 (2006) 1433-1439.

[17] M.J. Ross, Impedance Spectroscopy: Emphasizing Solid Materials and Systems, Wiley, New York, 1987.

[18] Q. Wang, J.E. Moser, M. Grätzel, Electrochemical impedance spectroscopic analysis of dye-sensitized solar cells, J. Phys. Chem. B 109 (2005) 14945-14953.

[19] J. Bisquert, Theory of the impedance of electron diffusion and recombination in a thin layer, J. Phys. Chem. B 106 (2002) 325-333.

[20] A. Hauch, A. Georg, Diffusion in the electrolyte and charge-transfer reaction at the platinum electrode in dye-sensitized solar cells, Electrochim. Acta 46 (2001) 3457-3466.

[21] R. Andrews, D. Jacques, A.M. Rao, F. Derbyshire, D. Qian, X. Fan, E.C. Dickey, J. Chen, Continuous production of aligned carbon nanotubes: a step closer to commercial realization, Chem. Phys. Lett. 303 (1999) 467-474.

[22] J. Liu, A.G. Rinzler, H.J. Dai, J.H. Hafner, R.K. Bradley, P.J. Boul, A. Lu, T. Iverson, K. Shelimov, C.B. Huffman, F. Rodriguez-Macias, Y.S. Shon, T.R. Lee, D.T. Colbert, R.E. Smalley, Fullerene pipes, Science 280 (1998) 1253-1256.

[23] C. Longo, J. Freitas, M.A. De Paoli, Performance and stability of $\mathrm{TiO}_{2} /$ dye solar cells assembled with flexible electrodes and a polymer electrolyte, J. Photochem. Photobiol. A: Chem. 159 (2003) 33-39.

[24] M.C. Bernard, H. Cachet, P. Falaras, A. Hugot-Le Goff, M. Kalbac, I. Lukes, N.T. Oanh, T. Stergiopoulos, I. Arabatzis, Sensitization of $\mathrm{TiO}_{2}$ by polypyridine dyes-role of the electron donor, J. Electrochem. Soc. 150 (2003) E155-E164.

[25] G. Schlichthorl, S.Y. Huang, J. Sprague, A.J. Frank, Band edge movement and recombination kinetics in dye-sensitized nanocrystalline $\mathrm{TiO}_{2}$ solar cells: a study by intensity modulated photovoltage spectroscopy, J. Phys. Chem. B 101 (1997) 8141-8155.

[26] G. Schlichthorl, N.G. Park, A.J. Frank, Evaluation of the charge-collection efficiency of dye-sensitized nanocrystalline $\mathrm{TiO}_{2}$ solar cells, J. Phys. Chem. B 103 (1999) 782-791.

[27] R. Kern, R. Sastrawan, J. Ferber, R. Stangl, J. Luther, Modeling and interpretation of electrical impedance spectra of dye solar cells operated under open-circuit conditions, Electrochim. Acta 47 (2002) 4213-4225.

[28] A. Kay, M. Grätzel, Dye-sensitized core-shell nanocrystals: improved efficiency of mesoporous tin oxide electrodes coated with a thin layer of an insulating oxide, Chem. Mater. 14 (2002) 2930-2935.

[29] Y. Diamant, S.G. Chen, O. Melamed, A. Zaban, Core-shell nanoporous electrode for dye sensitized solar cells: the effect of the $\mathrm{SrTiO}_{3}$ shell on the electronic properties of the $\mathrm{TiO}_{2}$ core, J. Phys. Chem. B 107 (2003) 1977-1981.

[30] J.G. Chen, V. Suryanarayanan, K.M. Lee, K.C. Ho, On the use of triethylamine hydroiodide as a supporting electrolyte in dye-sensitized solar cells, Sol. Energy Mater. Sol. Cells 91 (2007) 1432-1437. 